\title{
Effect of library orientation on School libraries in Japan
}

\author{
Sho Enomoto \\ Graduate School of Library, Information and Media Studies, University of Tsukuba \\ Japan \\ senomoto@klis.tsukuba.ac.jp
}

\begin{abstract}
To make the better use of the school library, library orientation plays a very important role. Library orientation is not only teach students how to use the library, but also have effects the Life-long learning. This study aims to clarify the following two points; (1) whether the students remember or not about library orientation, (2) the effects of the library orientation in the school library. The data were collected via a questionnaire survey with 1,540 freshman belong to the university of Tsukuba. A total number of $226(14.7 \%)$ survey responses were collected from the students. Students who remember about library orientation was 58 percent. The result of the study suggests that if the library orientation has been carried out effectively, it will be attract more students to come to the library. Otherwise, the use of the library will become less and less, and will be forgotten in the end.
\end{abstract}

Keywords: School library, Library orientation, User education, Life-long learning, Information Literacy

\section{Introduction}

In Japan, Ministry of Education, Culture, Sports, Science and Technology-Japan (MEXT) promote Life-long learning. MEXT approved the Basic Plan for Promoting Education $2^{\text {nd }}$ (MEXT, 2013) that promoted Life-long learning and utilizing Information and Communication Technology (ICTs). Most of school libraries and educational institutions following this plan to practice their education. On the other hand, annual survey of the school library is being done by the Japan School Library Association (JSLA) Research Department in every year. This study focus on how many students read books regularly in a month. The result of this study suggest that if the level of study goes up, students will less read books. One of each pair of high school students read no books at all in a month, because high school students become busy in studying for entrance examination or club activities. On the other hand, some students think that there are no book they are interested in, other students consider that library itself is 
not attractive for them. To solve this situation, the effective library orientation seen to be needed.

To make better use of the school library, library orientation plays a very important role. Library orientation is not only teach students how to use the library, but also have effect on the Life-long learning. This study aim at supporting a good library orientation at the school library.

\section{Literature review}

According to the JSLA report of $2015,93.8 \%$ in elementary schools, $87.3 \%$ in junior high schools, and $93.3 \%$ in high schools that library orientation have been carried out (JSLA, 2015). Table 1 shows that who in charge of the library orientation. Teacher librarian in charge $8.1 \%$ at elementary school, $23.5 \%$ at junior high schools, and $18.6 \%$ at high schools. On the other hand, Teacher (NOT teacher librarian) in charge $5.0 \%$ at elementary school, $18.2 \%$ at junior high schools, and $37.1 \%$ at high schools. School librarian in charge $59.1 \%$ at elementary schools, $53.3 \%$ at junior high schools, and $71.1 \%$ at high schools. Moreover, class teacher in charge $60.2 \%$ at elementary schools, $13.9 \%$ at junior high schools, and $20.6 \%$ at high schools. Despite the existence of teacher librarian, there are few school libraries that teacher librarian in charge of the library orientation. In this result, there is a question that whether the library orientation are substantially function.

Table 1: Who in charge of the library orientation?

\begin{tabular}{lrrr}
\hline \multicolumn{1}{c}{ Name of Schools } & Elementary school & Junior high school & High school \\
\hline Teacher librarian & $8.1 \%$ & $23.5 \%$ & $18.6 \%$ \\
Teacher (NOT teacher librarian) & $5.0 \%$ & $18.2 \%$ & $37.1 \%$ \\
School librarian & $59.1 \%$ & $53.3 \%$ & $71.1 \%$ \\
Class teacher & $60.2 \%$ & $13.9 \%$ & $20.6 \%$ \\
Other & $4.2 \%$ & $24.1 \%$ & $20.6 \%$ \\
\hline
\end{tabular}

Ohno said that the library orientation in the school library in Japan are very poor compared with the academic library in the book of "To understand form zero about academic library" (Ohno, 2010). However, Ohno did not mentioned about the reason. There are 20,601 elementary schools, 10,484 junior high schools, and 4,939 high schools in Japan. So it is a big issue to do the research among all the school library. Hence, it has not been evaluated the effective of the library orientation in the school libraries by now. 


\section{Research question}

This study aims to clarify the following two points; (1) whether the students remember or not about library orientation, (2) the effects of the library orientation in the school library.

Students remember about the library orientation in their school such as elementary schools, junior high schools, and high schools. For each of the school library orientation was carried out or not, or do not remember. What does the library orientation give effects for students. For example, students who attended the library orientation, change the purpose of using the school library, whether frequency of use the school library was change or not. Moreover, this study will reveal that students who attended the library orientation, whether there is an experience of using the school library in the classroom.

\section{Materials and Methods}

Library use and library use frequency are estimated to be affected by the library orientation that has been carried out in the school library. However, the inquiry about the presence or absence of the implementation of the library orientation to the school library is difficult from the abundance of the number of schools. For students who belong to a particular university in the present study, ask whether there was the library orientation in the school library. By carrying out the survey of students to enrol in university from all over the country, it is possible to eliminate the bias due academic area school differences and regional differences of those surveyed, according to the liberal arts and sciences. Storing whether received the library orientation includes the possibility that fade over time. Examine the change in the storage of library orientation over time.

The data were collected via a questionnaire survey with 1,540 freshman belong to the university of Tsukuba. University of Tsukuba is National Research University in Japan which have 9 faculties, 25 departments, and 8 graduate courses. Freshman remember about the library orientation in the school library more clearly compared with the upperclassman. There are about 10,000 undergraduate students, 6,000 graduate students, and 2,000 faculty staffs so that we get sufficient samples to statically analysis. Students come from over the country so that locality bias is low compare to the general university. Questionnaire composed to some questions such as experience of library orientation in the school library, purpose of use school library, and face sheet. Questionnaire was distributed to the students in freshman seminar which all freshman should attend. In the end of the freshman seminar, we collect the 
questionnaires. And we also asked the students to put the questionnaire answer to a box which has been set in the entrance of the library.

\section{Results}

Table 2 depicts the number of respondents who answered the questionnaire. A total number of $226(14.7 \%)$ survey responses were collected from the students.

Table 2: The number of respondents

\begin{tabular}{lrrr}
\hline \multicolumn{1}{c}{ Name of Schools } & Students & \multicolumn{2}{c}{ Respondents } \\
\hline Humanities and Culture & 247 & $50 \quad(20.2 \%)$ \\
Social and International Studies & 170 & 15 & $(8.8 \%)$ \\
Human Sciences & 127 & 7 & $(5.5 \%)$ \\
Life and Environmental Sciences & 264 & $46 \quad(17.4 \%)$ \\
Science and Engineering & 485 & $69(14.2 \%)$ \\
Informatics & 247 & $39(15.8 \%)$ \\
Total & 1,540 & $226(14.7 \%)$ \\
\hline
\end{tabular}

Table 3 shows that the frequency of the school libraries. The school library of elementary school were more used than the junior high school and high school. Focus on the difference between school year grade and use frequency of the school library, there are no significant difference in each school library except "High school grade 3". "High school grade 3" students use school library more compare to the "High school grade 1" and "High school grade 2", due to entrance examination, the "High school grade 3" students are prefer to they use school library to study. 
Table 3: Use frequency of the school library use

\begin{tabular}{|c|c|c|c|c|c|c|c|c|c|c|}
\hline $\begin{array}{c}\text { Name of Schools } \\
\text { and grade }\end{array}$ & \multicolumn{2}{|c|}{ Everyday } & \multicolumn{2}{|c|}{$\begin{array}{l}\text { A few times } \\
\text { per week }\end{array}$} & \multicolumn{2}{|c|}{$\begin{array}{l}\text { Once per } \\
\text { week }\end{array}$} & \multicolumn{2}{|c|}{$\begin{array}{c}\text { Once per } \\
\text { month }\end{array}$} & \multicolumn{2}{|c|}{ Not use } \\
\hline $\begin{array}{l}\text { Elementary school } \\
\text { grade } 1-3\end{array}$ & 26 & $(11.5 \%)$ & 50 & $(22.1 \%)$ & 50 & $(22.1 \%)$ & 41 & $(18.1 \%)$ & 59 & $(26.1 \%)$ \\
\hline $\begin{array}{l}\text { Elementary school } \\
\text { grade 4-6 }\end{array}$ & 32 & $(14.2 \%)$ & 55 & $(24.3 \%)$ & 52 & $(23.0 \%)$ & 41 & $(18.1 \%)$ & 46 & $(20.4 \%)$ \\
\hline $\begin{array}{l}\text { Junior high school } \\
\text { grade } 1\end{array}$ & 14 & $(6.2 \%)$ & 21 & $(9.3 \%)$ & 40 & $(17.7 \%)$ & 48 & $(21.2 \%)$ & 103 & $(45.6 \%)$ \\
\hline $\begin{array}{l}\text { Junior high school } \\
\text { grade } 2\end{array}$ & 17 & $(7.6 \%)$ & 21 & $(9.3 \%)$ & 36 & $(16.0 \%)$ & 51 & $(22.7 \%)$ & 100 & $(44.4 \%)$ \\
\hline $\begin{array}{l}\text { Junior high school } \\
\text { grade } 3\end{array}$ & 13 & $(5.8 \%)$ & 26 & $(11.6 \%)$ & 37 & $(16.4 \%)$ & 44 & $(19.6 \%)$ & 105 & $(46.7 \%)$ \\
\hline $\begin{array}{l}\text { High school } \\
\text { grade } 1\end{array}$ & 5 & $(2.2 \%)$ & 22 & $(9.8 \%)$ & 32 & $(14.2 \%)$ & 53 & $(23.6 \%)$ & 113 & $(50.2 \%)$ \\
\hline $\begin{array}{l}\text { High school } \\
\text { grade } 2\end{array}$ & 6 & $(2.7 \%)$ & 28 & $(12.4 \%)$ & 31 & $(13.7 \%)$ & 56 & $(24.8 \%)$ & 105 & $(46.5 \%)$ \\
\hline $\begin{array}{l}\text { High school } \\
\text { grade } 3\end{array}$ & 22 & $(9.7 \%)$ & 37 & $(16.4 \%)$ & 26 & $(11.5 \%)$ & 58 & $(25.7 \%)$ & 83 & $(36.7 \%)$ \\
\hline
\end{tabular}

Table 4 depicts the experience of library orientation in the school library. Students who responded "experienced" in elementary schools were $37.8 \%$, in junior high schools were $38.7 \%$, and high schools were $51.1 \%$. On the other hand, the students who answered "not experienced ever" in elementary schools were $27.6 \%$, in junior high schools were $33.3 \%$, in high schools were $30.7 \%$, and the answer do not remember, in elementary schools were $34.7 \%$, in junior high schools were $28.0 \%$, in high schools were $18.2 \%$. Students who experienced the library orientation in one of the school library are 131(58.2\%). It is lower than the overall $60 \%$ so that more than $40 \%$ of students not experience or remember the library orientation in the school library. This study analysed that whether the library orientation experience related to any such elements that purpose of use the school library. 
Table 4: Experience of library orientation in the school library

\begin{tabular}{lrlrlrr}
\hline \multicolumn{1}{c}{ Type of school library } & \multicolumn{2}{c}{ Yes } & \multicolumn{2}{c}{ No } & \multicolumn{2}{c}{ Not remember } \\
\hline Elementary school & 85 & $(37.8 \%)$ & 62 & $(27.6 \%)$ & 78 & $(34.7 \%)$ \\
Junior high school & 87 & $(38.7 \%)$ & 75 & $(33.3 \%)$ & 63 & $(28.0 \%)$ \\
High school & 115 & $(51.1 \%)$ & 69 & $(30.7 \%)$ & 41 & $(18.2 \%)$ \\
\hline
\end{tabular}

Table 5 shows that the purpose for using the school library. There are half of students whose purpose for using school library are "Reading books in the Library", "Borrowing Books". On the other hand, only few students use the school library for such as "Ask for Librarian", "Using computer or printer". As a purpose the difference was observed for each library "Killing time". "Killing time" was following to the large purpose of "Borrowing Books" and "Reading books in the Library" in the elementary school, it has decreased as the level of study goes up. However, "Learning relate for Tuition" and "Learning relate for Entrance Exam" have increased as the school year goes up. Some students answered "Other", all of that are "to attend student library commission".

Table 5: Purpose of use the school library

\begin{tabular}{lrrrrrr}
\hline \multicolumn{1}{c}{ Purpose of use the library } & \multicolumn{3}{c}{ Elementary School } & Junior high school & \multicolumn{2}{c}{ High school } \\
\hline Reading books in the Library & 118 & $(52.2 \%)$ & 87 & $(38.5 \%)$ & 91 & $(40.3 \%)$ \\
Borrowing Books & 135 & $(59.7 \%)$ & 103 & $(45.6 \%)$ & 86 & $(38.1 \%)$ \\
Ask for Librarian & 2 & $(0.9 \%)$ & 6 & $(2.7 \%)$ & 7 & $(3.1 \%)$ \\
Reading bringing books & 10 & $(4.4 \%)$ & 13 & $(5.8 \%)$ & 12 & $(5.3 \%)$ \\
Killing time & 73 & $(32.3 \%)$ & 65 & $(28.8 \%)$ & 46 & $(20.4 \%)$ \\
Using computer or printer & 2 & $(0.9 \%)$ & 5 & $(2.2 \%)$ & 9 & $(4.0 \%)$ \\
Learning relate for Tuition & 10 & $(4.4 \%)$ & 32 & $(14.2 \%)$ & 64 & $(28.3 \%)$ \\
Learning relate for Entrance Exam & 4 & $(1.8 \%)$ & 13 & $(5.8 \%)$ & 126 & $(55.8 \%)$ \\
Not remember & 15 & $(6.6 \%)$ & 22 & $(9.7 \%)$ & 6 & $(2.7 \%)$ \\
Not use & 20 & $(8.8 \%)$ & 45 & $(19.9 \%)$ & 25 & $(11.1 \%)$ \\
Others & 2 & $(0.9 \%)$ & 1 & $(0.4 \%)$ & 0 & $(0.0 \%)$ \\
\hline
\end{tabular}

In addition, this study revealed whether the library orientation experience related to the purposes of using school library by cross-tabulation analysis. Table 6 shows the cross-tabulation analyse of library purpose - library orientation experience. The services such 
as the lending and reading the materials in the school library, it was found to be significant and intended to be used for reading or studying. The results turn out that students who do not receiving any library orientation in the junior high school and high school, they also never use a library. Through a cross-tabulation analyse, the result also shows that there are no significant difference between the orientation experience and the frequency of use of the school library.

Table 6: Cross-tabulation analyse of library purpose - library orientation experience

\begin{tabular}{lrrr}
\hline \multicolumn{1}{c}{ Purpose of use the library } & Elementary School & Junior high school & High school \\
\hline Reading books in the Library & n.s & $* *$ & $* *$ \\
Borrowing Books & $*$ & n.s & n.s \\
Ask for Librarian & n.s & $*$ & n.s \\
Reading bringing books & n.s & $* *$ & n.s \\
Killing time & n.s & n.s & n.s \\
Using computer or printer & n.s & n.s & $*$ \\
Learning relate for Tuition & n.s & n.s & * \\
Learning relate for Entrance Exam & n.s & n.s & n.s \\
Not remember & n.s & $* *$ & $*$ \\
Not use &
\end{tabular}

$\left({ }^{*} p<.05,{ }^{* *} p<.001\right)$

Table 7 shows the results of the cross tabulation analysis for library orientation and library activities. The school has implemented a library orientation, it has become clear that class deployment using the library have been made. In addition, students who are in charge of the book committee of the school library is in high school, a possibility that has received a library orientation than students who are not in charge has been suggested. Alternatively, for the students who have received library orientation in some school library, there is a possibility that they have received a library orientation even in other school library was suggested. 
Table 7: Cross-tabulation analyse of education - library orientation experience

\begin{tabular}{lrrr}
\hline \multicolumn{1}{c}{ education } & Elementary School & Junior high school & High school \\
\hline Use the library in the classroom & $*$ & $* *$ & $* *$ \\
Student Library Commission & n.s & n.s \\
Library orientation in elementary & - & $* *$ & $* *$ \\
school & & & $*$ \\
Library orientation in junior high & & $* *$ \\
school & & $* *$ & - \\
Library orientation in high school & &
\end{tabular}

$\left({ }^{*} p<.05,{ }^{* *} p<.001\right)$

\section{Discussion}

To target the academic group of first-year students 1,540 people of the University of Tsukuba, as a result of the questionnaire in the library orientation carried out by the University of Tsukuba central library, obtained responses from first year of 226 patients (14.7\%). Students who responded that there is a thing that has received the library orientation until now was $58.2 \%$. Students who have not received library user education, test results that do not use the library was obtained. On the other hand, whether to affect the library user education and library use frequency if there is no significant difference, it still keep as a mystery. If do not received an explanation or library looks like, it is considered that there is no possible to use the library. However, after you understand what the library looks like, whether or not to use in the how much the frequency of, needs and library size and opening hours of the individual, is presumed to vary by the presence of another library such as the public library. Each of the trend of the use of the school library elementary school, junior high, high school one or two years following, it was found that the change in the time of high school third year. For example, with the level of study goes up, the library is begin to recognize that is the place to be learning other than read a book.

By library user education, to use to examine learning and reporting the school library or public library of materials, while rent or browse the library materials, is considered to but because they use the library as a workplace. In addition, library use in class is believed to be related to increasing him to goes up to the elementary school and junior high and high schools. A person who has received a library user education in schools, using the school library or public library of materials as a source of information, to rent or to browse a library of material for that. Besides, you can read a book in the book which brought in junior high school, to be such or the killing time, a result that related to the library of available educational experience was obtained. When it comes to high school, such as "to the learning related to the class," "for the exam study", a result that related to the purpose and use experience related to the learning was obtained. On 
the other hand, "never use the library before" people from the fact that there is somewhat a relationship in particular "have never received a library user education", library user education in schools, the premise of the original that use the library in the classroom to, is presumed to have been implemented. Related to have been expected, and the presence or absence of library user educational experience, with the relationship between the frequency of use of the library, as a result of the test, no significant difference was obtained. That if it is determined from the results heard about the library use of up to high school in qualitative research, to understand the library through the library user education, the library is what exists for me, use the library in terms of the decision, or do not use there is a possibility that the ruled. Evaluation of library user education in elementary school and junior high and high schools, the difference between the respective school species was observed. However, the presence or absence of each of library user education experience is because of the relationship, is considered biased to either if it had not received all it has received all of the library user education. Depending on the grade and students level of understanding, and at the same time to implement the library user education in stages, is considered that it is necessary to library user education What effect is there continuously evaluate how. By the evaluation, whether the effect is intended has come out, to examine whether the exit How If you do not come out, be inferred that towards the direction to improve the library user education.

\section{Limitation and future prospects}

Based on the findings of University of Tsukuba, the same investigation in other universities. Since the library user education is desirable to optimize in accordance with the goals and disciplines in each university, become a relatively large case study, it is difficult to compare the library user education in each of the university library.

However, be carried out in each university a similar investigation, it would not be able to show the theory of recursively library user education to find a common denominator.

\section{Conclusion}

According to the survey of JSLA in 2015, it was found that approximately 90 percent of the school library was implementing the library orientation. However, different from the results of JSLA, student who remember about library orientation was 58 percent. The result of the study suggests that if the library orientation has been carried out effectively, it will be attract more students to come to the library. Otherwise, the use of the library will become less and less, and will be forgotten in the end.

\section{Acknowledgment}

Investigation to thank everyone of the University of Tsukuba student who participated this study. In addition, we would like to thank deeply to every one of the University of Tsukuba 
Library who have readily agreed to distribute the questionnaire. Also I would like to thank everyone in the laboratory that was giving me the calibration and advice.

\section{References}

Japan School Library Association. (2015). 61st school reading research report. School Library, (781), 20-22.

MEXT. (2013). Basic Plan for Promoting Education 2nd. Retrieved May 30, 2016, from http://www.mext.go.jp/a_menu/keikaku/detail/_icsFiles/afieldfile/2013/06/14/13363 79_02_1.pdf

Ohno, T. (2005). To understand form zero about academic library. Japan Library Association.

\section{Biographical note}

Sho Enomoto is a graduate student of Graduate School of Library, Information and Media Studies, University of Tsukuba. He received his Bachelor of Library and Information Science in College of Knowledge and Library Sciences, School of Informatics, University of Tsukuba. His primary research interest is on information literacy education in academic library, 